\title{
XVII. Official report of a fall of Aërolites near grenade, seven leagues to the N.N.W. of Toulouse, on the 10th of April 1812
}

\section{D'Aubuisson}

To cite this article: M. D'Aubuisson (1814) XVII. Official report of a fall of Aërolites near grenade, seven leagues to the N.N.W. of Toulouse, on the 10th of April 1812, Philosophical Magazine Series 1, 44:196, 100-104, DOI: $10.1080 / 14786441408637420$

To link to this article: http://dx.doi.org/10.1080/14786441408637420

曲 Published online: 27 Jul 2009.

Submit your article to this journal $[\pi$

Џll Article views: 2

View related articles 


\section{Official Report of a Fall of Acrolites near Girenals.}

of nature, and in the processes of the arts, have necessarily caused it to occupy a great portion of the attention of chemists; and being of such importance, and in contant operation, it is not extrawrdinary, that a greater number of phænomena should be attributed to it, than it really produces.

In the viens that I have rentured to develop, neither oxygen, chlorine, or fluorine, are asserted to be elcments; it is only asserted that, as yet, they have not been decomposed.

As the investigation of nature proceeds, it is not inprobable, that other more subtile bodies belcnging to this class will be discovered; and, perhaps, some of the characteristic lifferences of those substances, which apparently give the same products by analysis, nay depend upon this circumstance.

The conjecture appears worth lazarding, whether the carbonaceous matter in the diamond may not be united to an extremely light and subtile principle of this kind, which has hitherto escaped detection, but which may be expelled, or newly combincd, during its combustion in oxygen. 'That sone chemical difference must exist between the hardest and most beautiful of the gems and charcoal, between a non-conductor and a conductor of electricity, it is scarcely possible, notwithstanding the elaborate experiments that have been made on the subject, to doubt : and it seems reasonable to expect, that a very refined or perfect chemistry will confirm the analogies of nature, and show that bodies cannot be exactly the same in composition or chemical nature, and yet totally different in all their physical properties.

XVII. Official Report of a Fall of Rërnlites near Grenale, seven Leagues to the N.N.Wr. of Toulouse, on ihe 10 th of April 1812. By M. D'Aurusson, Chite Fingineer of Mines in France ${ }^{*}$.

$\mathrm{O}_{\mathrm{N}}$ the 10th of April 1812, the air was colder than it had been for a few days; the themometer marked only $5^{\circ}$ about eight in the evening, when the phenomeuon took place: it had rained a great part of the day, and the sky was almost entirely covered with thick clouds

At the above hour a brilliant light was seen in the atmosphere at Toulouse, and for several leagues around: this was followed by a very loud detonation. It was thought at first that the powder magazine of Toulouse had been blown up; and when it

* Journal des Mines, vol. xxxi. p. 410.-The interruption of our communications with France prevented our laying this paper suoner before our readers.-EDIT. 
was discovered that this was mfounded, the light and noise were ascribed to sonie extraordinary meteor; for the state of the atmosphere and the force of the explosion did not admit of the idea of its being a simple clap of thunder. A few days afterwards it was discovered that this phenomenon had been accompanied with a shower of stones two leagues W.N.W. of Grenade, in the conmune of Buryave, (department of the Upper Garonne,) and of Camville and Verdun (department of the Tarv and Garonne). Some specimens were sent to the prefect of the Upper Garonne, and this magistrate appointed a commission composed of M. Sigret, of the Academy of Sciences; Marqué-Victor, Professor of Piysies ; Carney, Professor of Mathematics ; and myself, in orler to proceed to the spot and collect the details of the phriomenon. We accordingly gained the following information :

\section{Circumstances observed in the Aimosphere.}

The light which spread over the atmosphere appeared all at once. Although the sun had set for an hour and a half, and the air was dark, the light was so brilliant that the Mayor of Grenade informed us that he could read the smallest characters in the streets of the town; and the Mavor of Camville compared it to the light of the sun; adding, that the town clock was as visible as at noon day, and that a pin might have been picked up from the streets.

The exact duration of this light was not remarked. Some persons estimated it at two minutes; others at one, and others still less; but the fact is, that the light was continuous, and not instantancous like that of lightning.

The sky aromel being dark, the boly which produced this light could not be seen. Scarcely had it disappeared in the pluce where the aerolites fell, when there were heard in the air three strong detonations similar to the report of large pieces of eanuon: they succeeded each other rapidly, and almost without any interval.

Their noise was such that they were heard at Castres, twenty leagries from the spot where the stones fell. They were distinguibled from each other in the neighbourhood of this spot alowe; some persons informed us that they were of equal strength; others sad that their intensity sarually diminished.

We attempted in vain to collect information as to the interval which elapsed between the light and the detonations, in order to obtain some data as to the distance and height at which they had taken place.

They were followed by a very loud noise, which some compared to that of several heavy carriages rolling at once upon the G 3 pavement; 


\section{2}

Official Report of a Fall of Aerrolites near Grenade.

pavement; others compared it to the sound of several drums; and others to a strong fire of musketry from the Spaniards having invaded the country.

The noise was heard not only where the stones fell, but also at Grenacle and Toulouse ; it was heard for nearly a quarter of an hour, according to some persons: but although this is of course exaggerated, I camnot help thinking that it lasted a minute at least.

It came from the N.E. and proceeded to the S.E. The peasants who gave us the most correct information, heard it pass over their heads towards Toulouse, and gradually cease in that direction.

After the rolling noise had passed over the ground situated between the farms of la Bordette and la Praclere, a sharp hissing noise was heard, which ended in considerable shocks, similar to grape shot striking the ground : these phænomena were produced by the fall of the aêrolites.

\section{Circumstances olserved on the Ground.}

I now give the information received, as to the aërolites which were collected or heard to fall.

1. The inhabitants at the little farm called la Bordette distinctly heard two aërolites fall; one to the northward in a field adjoining, which they have not yet found: the other was found about 50 paces to the sonth-east: the fragment which we have weighs three ounces, and the whole stone did not weigh six.

2. At the cottage called Paris ( 300 metres above Pemejan) the inhabitunts vere at the door listening to the rolling noise over their heads, when they heard the noise of a body which fell in front of thern. The master of the house then went back through the honse to shut the dom of a stable, and when there the heard a second lar; e body fall. The interval between the two must have been about 75 seconds. This fact is of importance.

3. At Pemejan, the inhabitants, equally alamed at a stone witich fell near them, took reluge in the house; when they heard a serond hissing sound, followed by the noise of a body falling on the roof. Next day they found a tile broken, and a stone weighing about three ounces resting on the lath. Having carefully examined this spot, I found no contusion, nor any mark of fire, upon the wood of the roof. In the vicinity of the farm two stones were found which weighed a few ounces only.

4. At Richard, after the rolling noise, an explosion was heard in the air, and next day a stone weighing eight ounces. was found. 
Official Report of a Fall of Aïrolites near Grenade. 103

5. At Pradere, there fell, about a pace from the house, with considerable noise, and more than a minute after the detonations, an aerrolite weighing two pounds. It was not entirely sumk in the earth, and was not perceived until two days afterwards. A few seconds afterwards a smaller stone fell 40 paces in front of the house.

We did not learn for certain, notwithstanding some information to that effect, that any aerrolites fell beyond the linits marked by the places which we have mentioned.

The quantity of the ärolites which actually iell must not be inferred from the small number which was collected. It was night when they fell, and nost of the inhabitants were in bed: the ground on which they fell was partly in grass and partly ploughed up: into the latter many were no doubt sunk, so that it is more than probable, that a nuch more considerable quantity fell that what is mentioned above: in short, all that were collerted fell close to the houses, and of course were easily discovered. The whole tbat fell, therefore, may fairly be estimated at upwards of 100 ; nit, perhaps at 1000 .

Mineralogical Character of the Aerolites.

They were so like each other that the description of one will suffice. They were from three to eight ounces in weight, and one only weighed two pounds. They consist of a homogeneous paste of a stony nature, containing a very great quantity of small particles of iron in the metallic state, and very malleable. They do not affect any particular form. Their surface presents every where softened and rounded angles, nearly like those of a body which had begim to fuse. It is a very thin crust, like a coarse varnish or superficial coating; somerimes however it is thicker, but rarely exceeds a quarter of a line. It is of a blackishbrown colour.

The interior is of an ash gray. It becomes deeper, and exhibits spots of yellow ochre, when exposed to the contact of the air. The fracture is earthy with coarse grains, or rather granulous like freestone: it is rough to the touch.

With the exception of the metallic points, it is entirely dull: rasping makes it shine a littie, in consequence of the ductility of the iron, as we shall soon see.

These aërolites are easily broken and easily pulverized. Their fall even upon soft earth has broken most of them. They are semi-hard (i.e. they scratch glass). The crust only is hard, and gives some sparks with steel.

The specific gravity of six specimens varied only from $3 \cdot 66$ to $3 \cdot 71$. 


\section{Official Report of a Fall of Aerolites near Grenade.}

They are absolutely opaque, sour, do not stick to the tongue, and do not sensibly absorb water in whicli they are plunged.

Thin fragments, when exposed to the blow-pipe, became black, and were covered with black globules at some points : their surface was in this state similar to the crust of entire aërolites.

The iron was in considerable quantities, being more than a third of their weight: it is not however very conspicuous to the naked eye, on account of the smallness of the particles; but they are evident when the specimen is rubbed or polished. The iron, which is very malleable, is then spread by the hard body, and forms a small scale or stud : like a piece of bright lead. This metalic aspect is particularly visible at the surface on the spot. struck by the steel. Tine surfaces exposed by the lapidary's wheel present, on a gray ground, small metallic spots, and remind us of certain jaspers, containing dendrites of silver, which are found polished in mineralogical cabinets.

The great quautity of jron contained in these aërolites renders them of course very susceptible of the magnetic influence. But they exhibited no traces of polarity; and the phænomena of attraction only, but none of repulsion, were ever exhibited.

\section{Ol'servations.}

I shall hazard no conjectures, but only remark that three facts conspicuously arise from the foregoing descriptions:

1. The space or district occupied by the ae rolites of Grenade, is too limited to suppose that the point at which they were separated from each other was very high abeve the surface of our globe. They seem to have been fragments of a large mass which passed from N.W. to S.E., and which was broken, several times perhaps, at the time of the sucressive detonations which were heard in the atmosphere. The strength of the latte: seems to indicate that they took place in a very dense medium, and consequently at a small height.

2. After their separation, the fragmerts of this mass must have undergone a heat capable of fusing their surface : for each on reaching the ground was entirely covered with a varnish, or blackish coating, evidently produced by fusion.

3 . The light seen in the atmosphere seems to have been an effect of the deflagrations of the aerolitic mass; for it appeared suddenly like lightning, and was followed, or rather accompanied, by detonations, the interval between the light and the noise being undoubtedly the mere effect of distance. This light must have commenced by being very feeble, and must have gradually increased afterwards, if it had been produced by the arrival of a luminous meteor in our atmosphere. 